\title{
MICROBIAL DIVERSITY IN TRACE WATER OF JET FUEL IN VIETNAM
}

\author{
Lai Thuy Hien*, Pham Thi Hang, Vuong Thi Nga, Hoang Hai \\ Dept. Petroleum Microbiology, Institute of Biotechnology, VAST, Hanoi, Vietnam \\ Nobuyasu Yamaguchi, Katsuji Tani \\ Graduate school of Parmaceutical Sciences, Osaka University, 1-6 Yamada - Oka, \\ Suita, Osaka 565-0871, Japan
}

Received 15 August 2006

\section{INTRODUCTION}

Microorganisms in petroleum product, including jet fuel, have been found by some English and American authors since the 20's of the last century. In 1958, after Bakanaukas isolated many microorganisms in jet fuel JP4, this topic was especially concentrated. Most of microorganisms living in jet fuel are able to degrade hydrocarbon of the fuel to obtain energy and carbon source for their growth. The presence of microorganisms in jet fuel not only brings about the lost of fuel in store process, but also briefly changes the component and structure of jet fuel. More over, the products of their metabolism, such as organic acids, alcohols, $\mathrm{H}_{2} \mathrm{~S}, \ldots$ are corrosive. Hence, they cause many problems for fuel reservoirs and tanks, leak plugging pipelines. Besides, filter system and plugging pipeline can become obstructed because of microorganisms' biomass. This influences the plane safety. Therefore, many countries in the world consider microorganisms criteria as an important standard to estimate the jet fuel quality $[4,7,12]$.

From 1985 to 1990, in our country, Vietnam, there were some science projects about microorganisms in TC1 fuel [9]. At the present, as all country in Asia, Vietnam used to utilize and import hundred tons of jet A1. Tropical climate of Vietnam is the suitable condition for growing of microorganisms. With $\mathrm{C}_{8}-\mathrm{C}_{18}$ alkane chains, jet fuel is carbon source for a lot of microorganisms, especially bacteria and fungi, which harmfully affect plane safety. Therefore, we aimed Vietnam airlines company to control the number of microorganisms in jet fuel of all Vietnam airplanes, as well as study on the diversity of microorganisms in trace water in fuel samples, looking for the reason why filter is obstructed to contribute to the jet fuel storing and safety in Vietnam $[3,10]$.

\section{MATERIALS AND METHODS}

- Collect JetA1 samples from two water valves in two airplane wings with specific equipment.

- Inoculate, isolate and estimate the number of microorganisms in selective media: $\mathrm{R}_{2} \mathrm{~A}$ and MPA for bacteria, Czapeck for fungi, Hansen for yeast, Gause for actinomyces, Gost -902374 for jet A1 degrading bacteria.

\footnotetext{
* Corresponding author e-mail: hien.pm@ibt.ac.vn
} 
- Observe microorganism cell morphology then photograph microorganisms under Japanese JEM 1010 electronmicroscopy.

- Identify some common species in JetA1 with biochemical tests of Biomerieux (API20NE, API50CHB, API 50CH)

- Study on the diversity of microorganism population by $16 \mathrm{~S}$ rDNA analysis and DGGE method.

- Estimate the chemical and biological changes of jet fuel affected by microorganisms with content method and gaschromatography.

- Treat the data with Pros Nelson 1987.

- Identify chemical and biological component of jet fuel filter in several planes to estimate the capacity of making obstructed filter of microorganisms.

\section{RESULTS AND DISCUSSION}

The results involved in three main parts:

A. Analyzing the number of microorganisms in trace water and fuel samples collecting from airplane at the time they land off.

B. Estimating the influence of microorganisms on chemical component of fuel.

C. Analyzing the microorganisms and chemical structure of fuel filter samples.

A. Analyzing the number of microorganisms in trace water and fuel samples collecting from airplane at the time they land off

\section{The number of microorganisms in fuel trace water samples from airplanes}

Table 1: The number of microorganisms in fuel trace water samples from airplanes of Vietnam airlines.

\begin{tabular}{ccccc}
\hline \multirow{2}{*}{ Sample on } & Sample & \multicolumn{3}{c}{ The number of microorganism (CFU/ml) } \\
\cline { 3 - 5 } & & Aerobic bacteria & fungi & JetA1 degrading \\
\hline 30.10 .02 & S7 - ASA & $1,2 \times 10^{7}$ & $<10^{1}$ & $<10^{1}$ \\
10.3 .03 & S7 - ASA & $7,6 \times 10^{6}$ & 0 & $<10^{1}$ \\
7.3 .03 & S7 - ASB & $5 \times 10^{4}$ & $<10^{1}$ & $<10^{1}$ \\
28.4 .03 & S7 - ASC & $1,5 \times 10^{7}$ & $1,6 \times 10^{2}$ & $<10^{1}$ \\
4.12 .02 & S7 - ASD & $4,7 \times 10^{6}$ & $\mathbf{6 , 6 \times 1 0 ^ { 5 }}$ & $<10^{1}$ \\
11.4 .03 & S7 - ASD & $10^{6}$ & $<10^{1}$ & $<10^{1}$ \\
20.1 .03 & S7 - ASE & $6,1 \times 10^{5}$ & $10^{1}$ & $<10^{1}$ \\
10.6 .03 & S7 - ASE & $2 \times 10^{7}$ & $3,5 \times 10^{1}$ & $<10^{1}$ \\
10.1 .03 & S7 - ASF & $6,6 \times 10^{6}$ & $1,5 \times 10^{1}$ & 0 \\
26.5 .03 & S7 - ASF & $\mathbf{1 , 2} \times \mathbf{1 0}^{\mathbf{8}}$ & $\mathbf{5} \times \mathbf{1 0}^{\mathbf{3}}$ & $<10^{1}$ \\
13.2 .03 & S7 - ASG & $2,4 \times 10^{7}$ & 0 & $<10^{1}$
\end{tabular}




\begin{tabular}{ccccc}
21.10 .02 & S7 - ASH & $\mathbf{1 0}^{\mathbf{1}}$ & $\mathbf{8 , 8 \times 1 0 ^ { 3 }}$ & $<10^{1}$ \\
23.1 .03 & S7 - ASH & $1,8 \times 10^{4}$ & $<10^{1}$ & $<10^{1}$ \\
9.12 .02 & S7 - ASI & $8,4 \times 10^{5}$ & $2,8 \times 10^{3}$ & $<10^{1}$ \\
16.1 .03 & S7 - ASI & $2,4 \times 10^{5}$ & $<10^{1}$ & 0 \\
14.4 .03 & S7 - ASI & $5,6 \times 10^{7}$ & $<10^{1}$ & $<10^{1}$ \\
23.12 .02 & A321 - 342 & $2 \times 10^{6}$ & $10^{3}$ & $<10^{1}$ \\
2.6 .03 & A321 - 342 & $4,4 \times 10^{7}$ & 0 & 0 \\
21.10 .02 & A321 - 346 & $2,4 \times 10^{6}$ & $2,8 \times 10^{1}$ & $<10^{1}$ \\
5.3 .03 & A321 - 346 & $1,3 \times 10^{6}$ & $<10^{1}$ & $<10^{1}$ \\
3.4 .03 & A321 - 346 & $4 \times 10^{6}$ & $10^{1}$ & $<10^{1}$ \\
23.1 .03 & F70 - 502 & $2,5 \times 10^{3}$ & 0 & $<10^{1}$ \\
21.1 .03 & F70 - 504 & $10^{6}$ & $2,5 \times 10^{1}$ & $10^{1}$ \\
21.10 .02 & $767-$ A769 & $7,5 \times 10^{4}$ & 0 & $<10^{1}$ \\
\hline
\end{tabular}

In all 24 trace water samples in jet fuel microorganisms are present. The minimum number of microorganisms is $10^{4} \mathrm{CFU} / \mathrm{ml}$ (S7-ASH on $10.21^{\text {st }} .02$ ) and the maximum number is $10^{8}$ CFU $/ \mathrm{ml}$ (S7-ASF on $5.26^{\text {th }} .03$ with $10^{8}$ bacteria/ml and $10^{3}$ fungi $/ \mathrm{ml}$ ).

Fungi are present in 19/24 analyzed samples and the maximum number of fungi is $6.6 \times 10^{5}$ $\mathrm{CFU} / \mathrm{ml}$ in S7-ASD sample on $12.4^{\text {th }} .02$. Only 5 samples have no fungi.

JetA1 degrading microorganisms are present in 21/24 samples. In some samples, there are both fungi and JetA1 degrading bacteria (S7-ASD, 12.4 $4^{\text {th }} .02$; A321-346, 10.21 ${ }^{\text {st }} .03$ ). Only in 3 samples, there are no JetA1 utilizing microorganisms.

In an airplane but in different times of sample collecting, the number of microorganisms is different, depending on: the collecting time, flight time, biocide treating time.

\section{The number of microorganisms in jet fuel samples}

Table 2: The microorganisms density in JetA1 fuel from planes of Vietnam airlines.

\begin{tabular}{ccccccc}
\hline \multirow{2}{*}{ Day } & Samples & \multicolumn{5}{c}{ Density of microorganism (CFU/ml) } \\
\cline { 3 - 7 } & & Bacteria & Fungi & Yeast & Actinomyces & $\begin{array}{c}\text { Jet A1 } \\
\text { degrading }\end{array}$ \\
\hline 30.10 .02 & S7 - ASA & $<10^{1}$ & $<10^{1}$ & 0 & 0 & $<10^{1}$ \\
10.3 .03 & S7 - ASA & $3 \times 10^{1}$ & 0 & 0 & 0 & $<10^{1}$ \\
7.3 .03 & S7 - ASB & $<10^{1}$ & $<10^{1}$ & 0 & 0 & $<10^{1}$ \\
28.4 .03 & S7 - ASC & $1,5 \times 10^{1}$ & $4,4 \times 10^{1}$ & 0 & 0 & $<10^{1}$ \\
4.12 .02 & S7 - ASD & $1,9 \times 10^{2}$ & $2,3 \times 10^{1}$ & 0 & 0 & $<10^{1}$ \\
11.4 .03 & S7 - ASD & $4 \times 10^{1}$ & $<10^{1}$ & 0 & 0 & $<10^{1}$ \\
20.1 .03 & S7 - ASE & $7,5 \times 10^{1}$ & $10^{1}$ & 0 & 0 & $<10^{1}$
\end{tabular}




\begin{tabular}{ccccccc}
10.6 .03 & S7 - ASE & $<10^{1}$ & $3,5 \times 10^{1}$ & 0 & 0 & $<10^{1}$ \\
10.1 .03 & S7 - ASE & $1,5 \times 10^{2}$ & $1,5 \times 10^{1}$ & 0 & 0 & 0 \\
26.5 .03 & S7 - ASF & $4 \times 10^{1}$ & $1,1 \times 10^{3}$ & 0 & $<10^{1}$ & $<10^{1}$ \\
13.2 .03 & S7 - ASG & $6 \times 10^{1}$ & 0 & 0 & 0 & 0 \\
21.10 .02 & S7 - ASH & $<10^{1}$ & $1,3 \times 10^{1}$ & 0 & 0 & $<10^{1}$ \\
23.1 .03 & S7 - ASH & $<10^{1}$ & $<10^{1}$ & 0 & 0 & $<10^{1}$ \\
9.12 .02 & S7 - ASI & $<10^{1}$ & $<10^{1}$ & 0 & 0 & $<10^{1}$ \\
16.1 .03 & S7 - ASI & 0 & $<10^{1}$ & 0 & 0 & 0 \\
14.4 .03 & S7 - ASI & $4,5 \times 10^{1}$ & $<10^{1}$ & 0 & 0 & $<10^{1}$ \\
23.12 .02 & A321 - 342 & $<10^{1}$ & 0 & 0 & 0 & $<10^{1}$ \\
2.6 .03 & A321 - 342 & $<10^{1}$ & 0 & 0 & 0 & 0 \\
21.10 .02 & A321 - 346 & $1,7 \times 10^{2}$ & $1,7 \times 10^{1}$ & 0 & 0 & $<10^{1}$ \\
5.3 .03 & A321 - 346 & $8 \times 10^{2}$ & $<10^{1}$ & 0 & 0 & $<10^{1}$ \\
3.4 .03 & A321 - 346 & $2 \times 10^{1}$ & $10^{1}$ & 0 & 0 & $<10^{1}$ \\
23.1 .03 & F70 - 502 & $1,3 \times 10^{1}$ & 0 & 0 & 0 & $<10^{1}$ \\
21.1 .03 & F70 - 504 & $2,8 \times 10^{2}$ & $2,5 \times 10^{1}$ & 0 & 0 & $10^{1}$ \\
21.10 .02 & $767-$ A769 & $1,7 \times 10^{2}$ & $1,7 \times 10^{1}$ & 0 & 0 & $<10^{1}$ \\
\hline
\end{tabular}

According to the table 1 and 2, microorganisms in JetA1 fuel in Vietnam are diverse with all representation: aerobic bacteria, JetA1 utilizing bacteria, yeast, actinomyces and fungi. Although, at the same time and place of sample collecting, in samples with trace water, the number of microorganisms is thousands higher than in fuel samples. This means that it is neccesary to control and drain water in reservoirs frequently, associate storing process with treating fuel filter during supplying plane. As a result, we will decrease the number of microorganisms markedly.

\section{DGGE analysis bacteria population in jet fuel taken from airplanes}

After isolation crude DNA of total population in jet fuel we carried out DGGE analysis. The results showed on following figure.

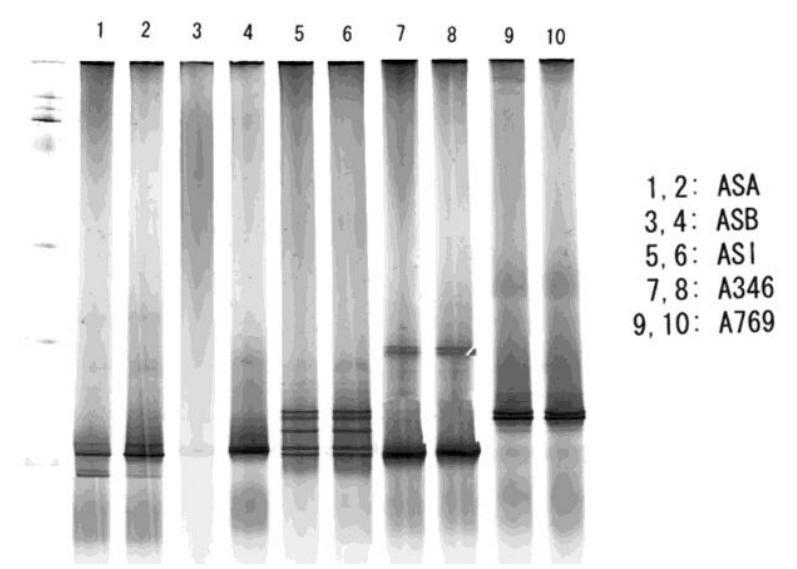

Fig. 1: DGGE of contaminents in jet fuel. 
There are many bands in some collumn. The results of DGGE very suitable with analyzed data on selective media (table 1 and 2). In the next step, we should cut these bands for futher analysis.

Basing on morphology and biophysical-biochemical characteristics, as well as biochemical tests and rDNA 16S, we clasified some common species in JetA1 fuel.

Negative Gram bacteria involved in Aeromonas, Chryseomonas, Pseudomonas (P. aeruginosa, P. putida, P. fluorescens, P. cepacia)

Positive Gram bacteria involved in Bacillus (B. coagulans, B. ciculans), Mycobacterium, Micrococcus

Fungi involved in Aspergillus (A. viridi, A .mutans, A. versicolor, A. sydovy, A. flavipes), Aureobasidium, Acremonium bacillispirilum, Paccillomyces variotii, Penicillium (P. lilacium, P. pullularia, P. nigricans, $P$. citrinum)

Yeast involved in Candida (C. tropicalis, C. albicans), Rhodoturula (R. glutinis)

Actinomyces involved in Streptomyces (S. argenteolus, S. orientalis, S. pulcher)

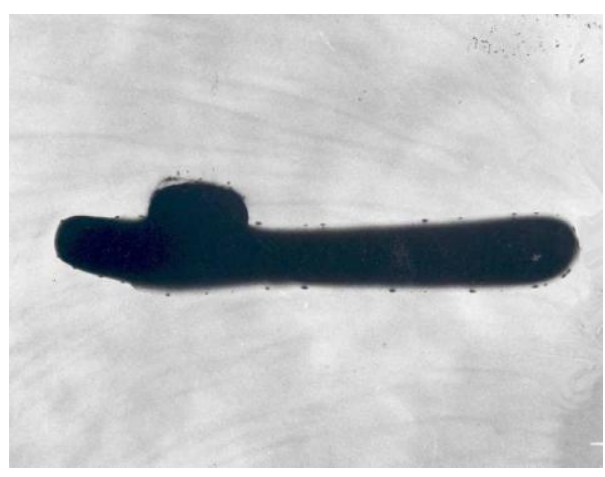

Bacillus coagulans ASB

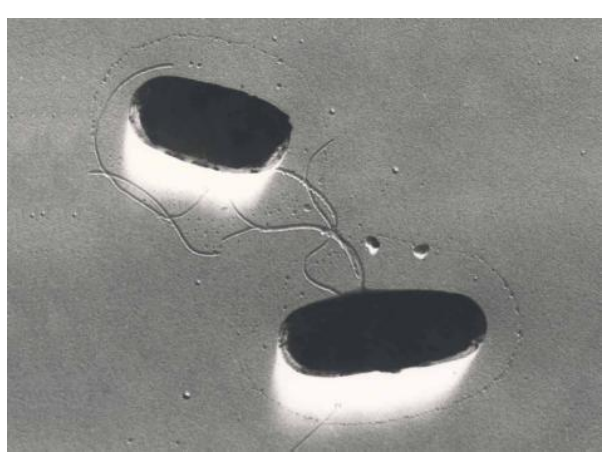

Chryseomonas ATR- KOC

Fig. 2: The morphology of Bacillus coagulans ASB and Chryseomonas OATR-KOC viewed with the electromicroscopy.

\section{The number of microorganisms in fuel samples from reservoir and filter}

Table 3: The ratio of microorganism groups in analyzed samples from reservoir and filter.

\begin{tabular}{ccccccc}
\hline \multirow{2}{*}{$\begin{array}{c}\text { The number of } \\
\text { microorganism } \\
\text { (CFU/ml) }\end{array}$} & $\begin{array}{c}\text { Terobic } \\
\text { bacteria }\end{array}$ & $\begin{array}{c}\text { Anaerobic } \\
\text { bacteria }\end{array}$ & $\begin{array}{c}\text { JetA1 } \\
\text { degrading } \\
\text { microorganism }\end{array}$ & Actinomyces & Fungi & Yeast \\
\hline$>10^{4}$ & 25 & 0 & 2 & 0 & 1 & 0 \\
$10^{2}-10^{4}$ & 46 & 1 & 34 & 5 & 20 & 3 \\
$10^{1}-10^{2}$ & 48 & 5 & 43 & 8 & 67 & 7 \\
$<10^{1}$ & 119 & 6 & 78 & 13 & 88 & 10 \\
Total & $\mathbf{2 3 8}$ & $\mathbf{1 2}$ & $\mathbf{1 5 8}$ & $\mathbf{2 6}$ & $\mathbf{1 7 6}$ & $\mathbf{2 0}$ \\
\hline
\end{tabular}


Table 4: The ratio of fuel samples having microorganism.

\begin{tabular}{ccccccc}
\hline & \multicolumn{5}{c}{ The ratio of fuel sample with microorganisms (\%) } \\
\cline { 2 - 7 } $\begin{array}{c}\text { The number of } \\
\text { microorganism } \\
(\text { CFU/ml) }\end{array}$ & $\begin{array}{c}\text { Aerobic } \\
\text { bacteria }\end{array}$ & $\begin{array}{c}\text { Anaerobic } \\
\text { bacteria }\end{array}$ & $\begin{array}{c}\text { JetA1 } \\
\text { degrading } \\
\text { microorganism }\end{array}$ & Actinomyces & Fungi & Yeast \\
\hline$>10^{4}$ & 15,0 & 0 & 1,2 & 0 & 0.6 & 0 \\
$10^{2}-10^{4}$ & 27,5 & 0,6 & 20,4 & 3,0 & 12,0 & 1,8 \\
$10^{1}-10^{2}$ & 28,7 & 3,0 & 25,2 & 4,8 & 40,1 & 4,2 \\
$<10^{1}$ & 71,3 & 3,6 & 46,7 & 7,8 & 52,7 & 6,0 \\
\hline
\end{tabular}

Table 5. The number of microorganism in jet fuel filter.

\begin{tabular}{ccccccc}
\hline Samples & $\begin{array}{c}\text { Aerobic } \\
\text { bacteria }\end{array}$ & $\begin{array}{c}\text { JetA1 } \\
\text { degrading } \\
\text { bacteria }\end{array}$ & $\begin{array}{c}\text { JetA1 } \\
\text { degrading } \\
\text { fungi }\end{array}$ & Actinomyces & Fungi & Yeast \\
\hline A320 & $3 \times 10^{8}$ & $2 \times 10^{5}$ & $10^{4}$ & $10^{4}$ & $10^{7}$ & $10^{7}$ \\
ATR-72 & $10^{7}$ & $10^{5}$ & $10^{4}$ & $10^{4}$ & 107 & $10^{7}$ \\
\hline
\end{tabular}

According to the table 3 and 4, the number of microorganism groups is in this order: Aerobic bacteria > fungi $>$ JetA1 utilizing bacteria $>$ actinomyces $>$ yeast $>$ anaerobic bacteria.

All of these microorganism can take part in the JetA1 fuel metabolism. Some strains are able to degrade fuel, others have capacity of utilizing mediator products produced by directly fuel utilizing bacteria. Therefore, the presence of all microorganisms affect on quality of fuel, especially on ashes weight after burning fuel. This amount of ashes is mechanics mingling which makes the engine corrosive and shorten the life.

We analyzed samples from all airplane of Vietnam airlines. According to the data in table, we rely that the plane A320 and TU134 are the most highly injected microorganisms (56-57\%). Particularly, it is very important to pay attention to JetA1 utilizing aerobic bacteria and fungi, because they created viscous membrane in filter, so they make filter obstructed.

\section{B. Estimating the influence of microorganisms on chemical component of fuel}

According to the table 6, all 3 trains highly utilize saturated hydrocarbon of JetA1 (from $17.47 \%$ to $55.89 \%$ ), especially C10 - C17 hydrocarbon chains. Pseudomonas sp.ASB can degrade $100 \%$ C18, Pseudomonas sp. ASJ degrades C15 - C17 hydrocarbon chain, and Aureobasidium pullularia $\mathrm{TX}_{1} \mathrm{~B}_{1}$ degrades $\mathrm{C} 9-\mathrm{C} 11$ hydrocarbon chain. Both bacteria and fungi change the JetA1 hydrocarbon component. 
Table 6. The change of saturated hydrocarbon of JetAl because of microorganisms.

\begin{tabular}{crrrrrrr}
\hline $\begin{array}{c}\text { The } \\
\text { number } \\
\text { of } \\
\text { carbon }\end{array}$ & $\mathrm{K}$ & $\begin{array}{c}\text { Hydrocarbo } \\
\text { n remaining } \\
(\mathrm{mg} / \mathrm{l})\end{array}$ & $\begin{array}{c}\text { Pseudomonas sp. ASB } \\
\text { utilized }\end{array}$ & $\begin{array}{c}\text { Pseudomonas sp. ASJ } \\
\text { H remaining } \\
(\mathrm{mg} / \mathrm{l})\end{array}$ & $\begin{array}{c}\text { Aureobasidium } \\
\text { untlilized } \\
\text { puria } \mathrm{TX}_{1} \mathrm{~B}_{1}\end{array}$ & $\begin{array}{c}\text { Hydrocarb } \\
\text { on } \\
\text { remaining } \\
(\mathrm{mg} / \mathrm{l})\end{array}$ & $\begin{array}{c}\% \\
\text { utilized }\end{array}$ \\
\hline C7 & 0 & 0 & - & 0 & - & 0 & - \\
C8 & 0 & 0 & - & 11 & - & 0 & - \\
C9 & 67 & 5 & $\mathbf{9 2 , 5 4}$ & 216 & - & 7 & $\mathbf{8 9 , 5 5}$ \\
C10 & 1304 & 362 & $\mathbf{7 2 , 2 4}$ & 695 & 25,54 & 333 & $\mathbf{7 4 , 4 6}$ \\
C11 & 1939 & 780 & $\mathbf{5 9 , 7 7}$ & 1125 & 17,79 & 993 & $\mathbf{4 8 , 7 9}$ \\
C12 & 2012 & 970 & $\mathbf{5 1 , 7 9}$ & 1156 & 9,24 & 1486 & 26,14 \\
C13 & 1404 & 766 & $\mathbf{4 5 , 4 4}$ & 839 & 5,20 & 1271 & 09,47 \\
C14 & 826 & 482 & $\mathbf{4 1 , 6 5}$ & 557 & 9,08 & 733 & 11,26 \\
C15 & 326 & 137 & $\mathbf{5 7 , 9 8}$ & 222 & $\mathbf{2 6 , 0 7}$ & 283 & 13,19 \\
C16 & 103 & 36 & $\mathbf{6 5 , 0 5}$ & 82 & $\mathbf{4 4 , 6 6}$ & 90 & 12,62 \\
C17 & 46 & 7 & $\mathbf{8 4 , 7 8}$ & 33 & $\mathbf{5 6 , 5 2}$ & 39 & 15,22 \\
C18 & 9 & 0 & $\mathbf{1 0 0 , 0 0}$ & 13 & - & 18 & - \\
C19 & trace & 0 & - & 0 & - & 0 & - \\
Total & $\mathbf{8 0 3 6}$ & $\mathbf{3 5 4 5}$ & $\mathbf{5 5 , 8 9}$ & $\mathbf{4 9 4 9}$ & $\mathbf{1 7 , 4 7}$ & $\mathbf{5 2 5 3}$ & $\mathbf{3 4 , 6 3}$ \\
\hline
\end{tabular}

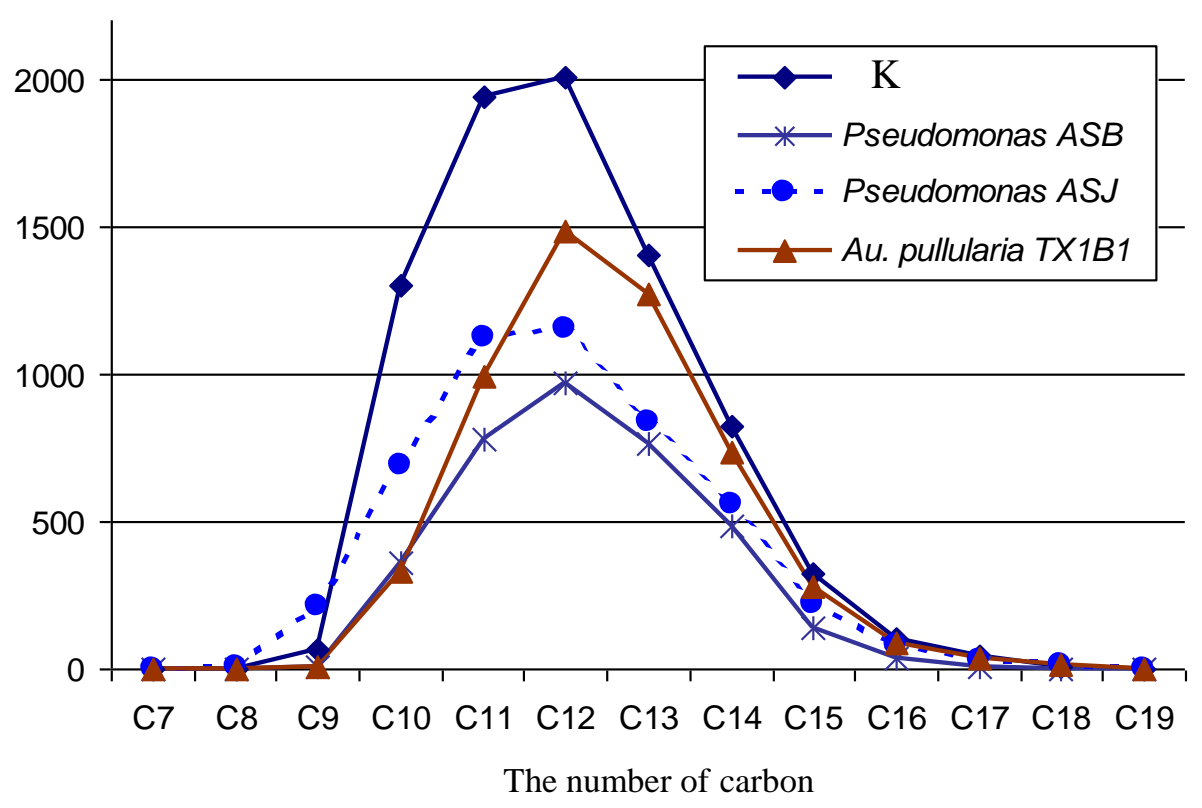




\section{Analyzing the microorganisms and chemical structe of fuel filter samples}

Table 7. Analyzing the amount of organic compound in sediment of ASG plane filter.

\begin{tabular}{ccc}
\hline Sample & $\begin{array}{c}\text { The amount of } \\
\text { sediment }(\mathbf{g} / \mathbf{m l})\end{array}$ & $\begin{array}{c}\text { The amount of organic } \\
\text { compound (\%) }\end{array}$ \\
\hline Sediment of filter before burning & 0,0327 & - \\
Sediment of filter after burning & 0,0124 & - \\
The amount of organic compound & - & 62,1 \\
The amount of inorganic compound & - & 37,9 \\
\hline
\end{tabular}

Usually, organic component is from 50 to $60 \%$ in sediment of filter, if this component is higher than $60 \%$, this means that after burning, the amount of organic compound is created by microorganisms. When the plane works this organic compound will make filter obstructed.

Table 8. The portion of infected microorganisms in jet fuel.

\begin{tabular}{cccc}
\hline Type of planes & $\begin{array}{c}\text { The number of } \\
\text { analyzed samples }\end{array}$ & $\begin{array}{c}\text { The number of } \\
\text { injected samples }\end{array}$ & Portion (\%) \\
\hline A320 & 109 & 61 & 56,0 \\
Boeing & 22 & 5 & 22,7 \\
Fokker & 20 & 5 & 20,0 \\
ATR72 & 30 & 7 & 23,3 \\
TU134 & 7 & 4 & 57,0 \\
\hline
\end{tabular}

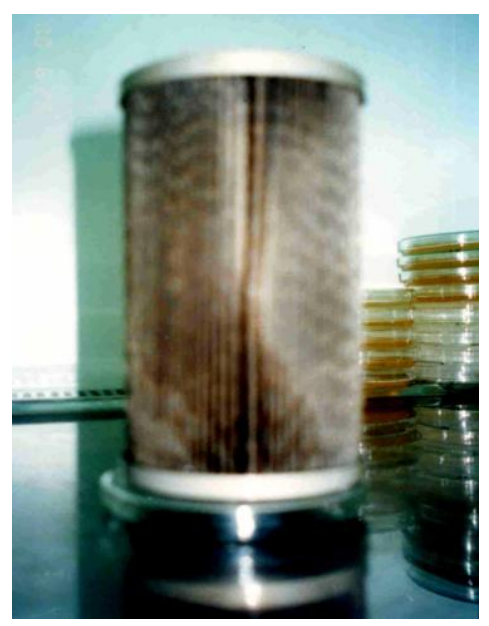

Fig. 3: Airplane filter. 


\section{The capacity of applying}

- We applied to control the number of microorganisms in jet fuel of Vietnam airlines

- We can apply to all storing units, petroleum and fuel storing in Vietnam

\section{CONCLUSION}

From analyzing more than 200 jet fuel samples, we have:

1. The number of microorganisms in trace water jet fuel is from $10^{4}$ to $10^{8} \mathrm{CFU} / \mathrm{ml}$ and the number of microorganisms is only from $10^{1}$ to $10^{3}$ in samples without water.

2. Basing on morphology and biophysical, biochemical characteristics, microorganisms found in Jet A1 fuel are: Aeromonas, Chryseomonas, Pseudomonas, Bacillus, Mycobacterium, Micrococcus, Candida, Rhodotorula, Aspergillus, Penicilium, Aureobasidium, Paecillomyces, Acremonium, Streptomyces

3. According to the result of analyzing organic and inorganic compound in filter, microorganisms are the reason that creates viscous membrane which make fuel obstructed. The main microorganism structures on fuel filter are fungi and bacteria.

4. Analyzing hydrocarbon component of JetA1 under the effect of 3 representation bacteria and 1 fungi strain, the capacity of growing and changing fuel component of microorganisms brings about the decrease the fuel quality.

5. It is necessary to control the number of microorganisms during fuel storing frequently, drain water perioudically and treat reservoirs with biocide when the number of bacteria is higher than $10^{2} \mathrm{CFU} / \mathrm{ml}$.

\section{REFERENCES}

1. Bento, F.M. and Gaylarde, C.C. (1998), Effect of additives on fuel stability - a microbiological study. In: LABS 3 - Third Latin American Biodegradation and biodeterioration Symposium, eds. C.C. Gaylarde, T.C. Barbosa and N.H.Gabilan, The British Phycological Society, UK, paper no. 10.

2. Bento, F.M. and Gaylarde, C.C. (1996), Microbial contamination of stored diesel oil in Brazil. Rev.Microbiol., 27: 192-196.

3. Dang Phuong Nga and Lai Thuy Hien (2001), Taxonomic characteristics of some acquainted positive Gram bacteria strains and their effects on the quality of Jet A1fuel. J. Biology. 23(2): 20-26.

4. Defene standard turbine fuel, aviation kerosene type JET A1. May 1996, DEF/STAN 91 91/2 (DERD 2494).

5. Ferrari M.D., Neirotti E., and Albornoz C. (1998), Occurrence of heterotrophic bacteria and fungi in an aviation fuel handling system and its relationship with fuel fouling. Rev Argent Microbiol. 1998 Jul-Sep; 30(3): 105-14.

6. Hill, E.C. and Hill, G.C. (1993), Microbiological problems in distillate fuels. Trans. Inst. Marine Eng., 104: 119 - 130.

7. IATA guidance material for aviation turbine fuels. Aprils, 1987. Canada.

8. Kampfer P., Uwe M., Michael E., Thomas H., and Hans J.B. (2007), Sphingomonas 
pseudosanguinis sp. nov., isolated from the water reservoir of an air humidifier. Inter. J. Syst. Evol. Microbiol. 57: 1342-1345.

9. Lai Thuy Hien, Dang Cam Ha, Ly Kim Bang, and Nguyen Thanh Hai (1988), Microbial contamination in TC1 fuel, in Vietnam. J. Biology 10(1): 5-9.

10. Lai Thuy Hien, Do Thu Phuong, Vu Phuong Anh, Dang Phuong Nga, Pham Thu Thuy, Hoang Hai, and Pham Thi Hang (1998), Microorganisms in Jet A1 fuel and alternative eliminating by biocides.Annual Report of IBT, NCST. Publishing House Science and Technique Hanoi 2000.

11. Litman, E.S. (1980), Microbiological contamination of fuels during storage. In Distillate Fuel Stability and Cleanliness, eds.L.L. Stavinoah and E.I. Henry, ASTM 04-751000-12, pp. 136-144.

12. Rauch, M.E., Harold, W.G., Sophie, M.R., Sharon, E.J., Charles, A.B., Randell, L.K., Rajesh, R.N., and Morley, O.S. (2006), Characterization of microbial contamination in United States air force aviation fuel tanks. J. Indust. Microbiol. Biotech. 33(1): 29-36.

13. Shennan, J.L. (1988), Control of microbial contamination of fuels in storage. In Biodeterioration 7, eds. D.R. Houghton, R.N. Smith and H.O.W.Eggins, Elsevier, Barking, pp. 248-254.

14. Solana, M.J.V. and Gaylarde, C.C. (1995), Fungal contamination and growth in various hydrocarbon fuels. In Biodeterioration and Biodegradation 9, eds. E. Bousher, M. Chandra and R. Edyvean, Rugby: Inst. Chem. Engs., pp. 621-628.

15. Whyte, L.G., Hawari, J., Zhou, I., Bourbonniere, L., Inniss, W.E., and Greer, C.W. (1998), Appl Environ. Microbiol., 64, 7: 2578-2584.

16. Yassin, A.F., Hupfer, H., and Schaal, K.P. (2006), Dietza cinnamea sp. nov. a novel species isolated from a perianal swab of a patient with a bone marrow transplant. Inter. J. Syst. Evol. Microbiol. 56: 641-645.

17. Yerushalmi, L. and Guiot, S.R. (1998), Appl. Microbiol. Biotechnol., 49: 475 -418. 